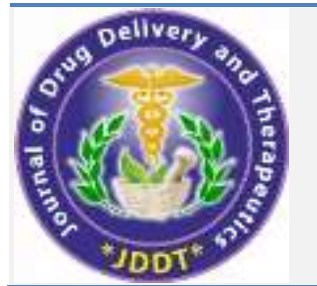

\section{Journal of Drug Delivery and Therapeutics}

Open Access to Pharmaceutical and Medical Research

Copyright (C) 2021 The Author(s): This is an open-access article distributed under the terms of the CC BY-NC 4.0 which permits unrestricted use, distribution, and reproduction in any medium for non-commercial use provided the original author and source are credited

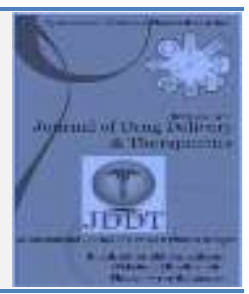

Research Article

\title{
Assessment of Depression, Anxiety and Stress among Healthcare Students during COVID-19 Pandemic: A Cross Sectional Study
}

\author{
Mahendra Kumar R1(i), R Reenal Naik ${ }^{2}$ (i), Rahul Kukarni³, Sanatkumar Nyamagoud ${ }^{*}$ (ii) \\ ${ }^{1}$ Assistant Professor, Department of Pharmacy Practice, KLE College of Pharmacy, Hubli, Karnataka, India-580031 \\ ${ }^{2}$ Department of Pharmacology, KLE College of Pharmacy, Hubli, Karnataka, India-580031 \\ ${ }^{3}$ Department of Pharmacy Practice, KLE College of Pharmacy, Hubli, Karnataka, India-580031
}

\section{Article Info:}

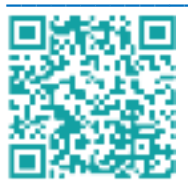

\section{Article History:}

Received 13 October 2021

Reviewed 03 December 2021

Accepted 08 December 2021

Published 15 December 2021

\section{Cite this article as:}

Mahendra Kumar R, Naik RR, Kukarni R,

Nyamagoud S, Assessment of Depression, Anxiety

and Stress among Healthcare Students during

COVID-19 Pandemic: A Cross Sectional Study,

Journal of Drug Delivery and Therapeutics. 2021;

11(6-S):92-99

DOI: http://dx.doi.org/10.22270/jddt.v11i6-S.5144

\section{*Address for Correspondence:}

Dr. Sanatkumar B Nyamagoud, Assistant Professor, Department of Pharmacy Practice, KLE College of Pharmacy, Vidyanagar, Hubballi 580031, India

ORCID ID: https://orcid.org/0000-0001-7108-166X

\section{Abstract}

Background: A Corona virus pandemic now has had a huge impact on quality of life all around the world. People's mental health has been affected by quarantine. The economic delays could have long term impacts on the psychology of students as they are more likely to be graduated later than they have expected. The number of factors contributed to gravitate the psychological disturbances including online education, financial worries and academic pressure.

Aims and Objectives: This Study was to determine the level of Depression, Anxiety and Stress among Students during COVID-19 Pandemic. Furthermore, to see if there's a correlation between demographic profile and the DASS-21.

Materials and methods: A cross-sectional survey was conducted among the healthcare students using DASS-21 which included a conventional DASS questionnaire along with demographic characteristics. A Google form link was shared through social media-WhatsApp and E-mail and data was collected and analyzed using excel sheet to examine the levels of depression, anxiety, and stress among students.

Results: The study enrolled a total of 303 students. The prevalence of moderate depression, anxiety, and stress was found to be $37.9 \%, 337.9 \%, 34.9 \%$ and $33 \%$, respectively. Males were represented up to 54.13 percent of the population, while females accounted for 45.87 percent. Female responders were more likely than their male counterparts to experience depression and anxiety, whereas stress levels were found to be comparable in both genders.

Conclusion: The average scores of depression, anxiety, and stress in this study were significantly high. Depression, anxiety, and stress are now all associated with a variety of causes. Students develop depression and anxiety as a result of a lack of academic and social life. Students may be stressed due to a lack of exercise and economic difficulties.

Keywords: Depression, DASS-21, Mental Health, Pandemic, Students, Social Life

\section{INTRODUCTION:}

In December 2019, the novel corona virus disease (COVID19) was discovered for the first time in Wuhan (Hubei Province, China). It began to spread from that point on, first in China and then throughout the world. ${ }^{1}$ Corona virus disease 2019 (COVID-19) is a new viral disease caused by the corona virus 2 which is enveloped, positive, singlestranded large RNA virus that cause severe acute respiratory syndrome (SARS-CoV-2). ${ }^{2}$

On January 30, the World Health Organization (WHO) declared the outbreak as a Public Health Emergency of International Concern (PHEIC) and a pandemic On March 11. ${ }^{3}$ COVID-19 quickly expanded to over 127 nations and territories throughout the world (corona virus update 2020, March 13). The number of confirmed cases had risen to 83,652 by February 28, 2020, including 4,691 positive cases and 87 deaths outside of China. From March to April 2020, almost all of the countries affected, declared a state of emergency to combat the spread of the virus. ${ }^{4}$

The first case of COVID-19 in India were reported in the state of Kerala, among three Indian medical students who had returned from Wuhan. ${ }^{5}$ As of 12 June 2021, India has the second- highest number of confirmed cases in the world (after the United States) with 29.3 million reported cases of COVID-19 infection and the third-highest number of COVID19 deaths (after the United States and Brazil) at 367,081 deaths. ${ }^{6}$ India has the largest number of cases in Asia. Currently India has 3,87,987 active cases (1.21\%) and $4,29,669$ deaths (1.34\%) across all its states(as per Aug 2021). ${ }^{7}$

The virus is spread by direct contact with infected person's respiratory droplets (which are produced by coughing and sneezing) and by touching virus-infested surfaces. The 
COVID-19 virus can survive on surfaces for several hours, but simple disinfectants can kill it. ${ }^{4}$

Almost the entire world is in a state of paralysis due to the severe outbreak of COVID-19. Taking a precautionary measure, India announced 'Janta Curfew' or lockdown from 7 am to 9 pm on 22 March 2020 where people were urged to stay inside their homes (Chandna \& Basu, 2020). Therefore, to contain the spread of fatal COVID-19, complete lockdown was announced for 21 days, that is, from 24 March 2020 to 14 April 2020 (ET Online, 2020). Due to this lockdown, people are prohibited from going out, except for emergencies like to buy only necessary groceries or medical supplies. A recent survey conducted by the Indian Psychiatry Society indicates $20 \%$ rise in patients suffering from mental illness (Lolwal, 2020). The lockdown situation distressed general public. ${ }^{8}$

To counterfeit, COVID-19 spread the countries initiated a series of measures to break the chain of infection and control the pandemic, including local and international travel bans, bans on large gatherings, suspension of public transport, closure of schools and universities and of business, social distancing, stay-at-home orders, and curfews. ${ }^{9}$

In addition to the physical impacts, COVID-19 can have serious effects on mental health of the people. ${ }^{10} \mathrm{~A}$ wide range of psychological outcomes have been observed during that time, at individual, community, national, and international levels. At the individual level, people are more likely to experience fear of getting sick or dying, feeling helpless, and being stereotyped by others. ${ }^{11}$

The fear of contacting the virus, lack of treatment, higher mortality associated with the virus, and uncertainty about when the virus would be controlled and when a vaccine would be available are the major factors that were found to be highly responsible in increasing psychological distress, adjustment, and even more serious mental health problems. Incidences were even noticed where some people could not handle the mental pressure, and as an escape from traumatizing reality, they committed suicide. ${ }^{12}$

Depression is a mood condition characterized by feelings of hopelessness, guilt, worthlessness, and helplessness, among other things. Anxiety is a psychological condition with cognitive, physical, emotional, and behavioral factors. Stress is defined as a condition in which an individual's adaptive ability is exceeded by environmental demands, resulting in psychological and biological alterations that may worsen. ${ }^{13}$ Early detection of these disorders is essential to provide psychological interventions for individuals experiencing these negative emotional conditions. ${ }^{9}$ Therefore, the current study was aimed at assessing the depression, anxiety and stress during the pandemic of COVID-19 among students using DASS-21 scale.4

\section{MATERIALS AND METHODS:}

A cross-section online survey was conducted between 26th April to 20th May 2021, during COVID-19 second wave. This study employed a quantitative research design as the aim of the study was to explore the level of depression, anxiety, and stress among the healthcare students. As the data collection was done in the middle of April 2021, a survey form through an online platform was used for the data collection during the COVID-19 pandemic lockdown period. The Google form link had been posted and circulated using various social media platforms such as WhatsApp and email. At the beginning of the survey, the study participants were informed about the details of the study goals for filling out the questionnaire and each participant provided their informed consent to take part in this study. All participants were told that their identity would be kept confidential and that the findings would only be used for study purposes. At the end total of 303 students participated in the present study.

\section{Study Tool:}

A DASS-21 scale was used to determine the level of depression, anxiety and stress among the Healthcare students. The first part of the questionnaire covered demographic information of the participants and the second part covered questions for the assessment of depression, anxiety and stress.

An abbreviated version of the depression, anxiety and stress scale (DASS-21) was used. The questionnaire consisted of 7 questions regarding Anxiety, 7 for depression, and 7 for stress. Each item was answered according to the presence and intensity of each symptom on response scale. Each scale had 7 items and its total score was calculated with sum of the items belonging to that scale and varied between $0-21$ points. Item $1,6,8,11,12,14$ and 18 belonged to stress scale, item $3,5,10,13,16,17$, and 21 to the depression scale and item $2,4,7,9,15,19$ and 20 to the anxiety scale.

Table 1: DASS-21 Questionnaire scores

\begin{tabular}{|l|l|l|l|}
\hline Category & Depression & Anxiety & Stress \\
\hline Normal & $0-4$ & $0-3$ & $0-7$ \\
\hline Mild & $5-6$ & $4-5$ & $8-9$ \\
\hline Moderate & $7-10$ & $6-7$ & $10-12$ \\
\hline Severe & $11-13$ & $8-9$ & $13-16$ \\
\hline Extremely severe & $14+$ & $10+$ & $17+$ \\
\hline
\end{tabular}

Each question was scored from 0 to 3 . If a student scored $>14$ for depression,>10 for anxiety and > 19 for stress, they were referred for further counseling. ${ }^{27}$

\section{Ethical clearance and Sample Size:}

The project proposal was reviewed and approved by the institutional ethical committee of KLE College of Pharmacy, Hubli. Sample size was estimated using the Rao soft sample size calculator. A minimum of 285 participants were required at a margin of error of $5 \%$, a $95 \%$ confidence interval (CI), and a population size of 1 billion at a $50 \%$ response distribution. However, we finally recruited 303 healthcare students into the study.

\section{Statistical analysis:}

All the data from the Google forms were directly imported into Excel spread sheets. Data was further checked for any errors or incomplete forms. Finally, we were able to obtain responses from 303 students without any errors. Data was further subjected to coding and final anxiety, depression and stress scores from the participants were calculated. Statistical analysis were carried out using SPSS Version 16.0.25 Association between the anxiety, depression and stress scores within the demographic characteristics were performed using chi-square test. A ' $p$ ' value of 0.05 was considered as statistically significant, 26

\section{RESULTS:}

The study included a total of 303 patients were enrolled in the study, Out of which $45.87 \%$ were male $(n=139)$ and $54.13 \%$ were female $(n=164)$, as shown in Table 2 . 
Table 2: Demographic findings of the study population

\begin{tabular}{|l|l|}
\hline Demographic Characters & Total [n(\%)] \\
\hline Age & \\
\hline $18-22$ & $226(74.58)$ \\
\hline $23-25$ & $69(22.77)$ \\
\hline 225 & $8(2.65)$ \\
\hline Gender & \\
\hline Male & $139(45.87)$ \\
\hline Female & $164(54.13)$ \\
\hline Educational status & \\
\hline Pharmacy & $140(46.2)$ \\
\hline Medicine & $103(33.99)$ \\
\hline BDS & $60(19.81)$ \\
\hline Residential status & \\
\hline Personal home & $246(81.18)$ \\
\hline Dormitory & $57(18.82)$ \\
\hline Marital status & \\
\hline Married & $6(1.98)$ \\
\hline Unmarried & $296(98.02)$ \\
\hline History of CoVID-19 & \\
\hline Yes & $25(8.26)$ \\
\hline No & $278(91.74)$ \\
\hline
\end{tabular}

The results of Age-wise categorization revealed that the mean age of the subjects was found to be $21.69 \pm 2.30$. The results demonstrated that subjects of age group between 1822 years were in majority accounting for $74.58 \%$ and $23-25$ years were $22.77 \%$ of the total population as shown in figure 1 and Table 2.

The study results also revealed that $46.2 \% \quad(n=140)$ of subjects were found to be from the pharmacy profession, $33.99 \%(n=103)$ were from medicine and $19.81 \%(n=60)$ were from BDS as shown in Figure 2 and table-1.

The result illustrated that $81.18 \%(n=246)$ subjects were found to be residing at their personal home and the number of subjects residing in dormitory were $18.82 \%(n=57)$ as shown in figure 3 table- 2 .

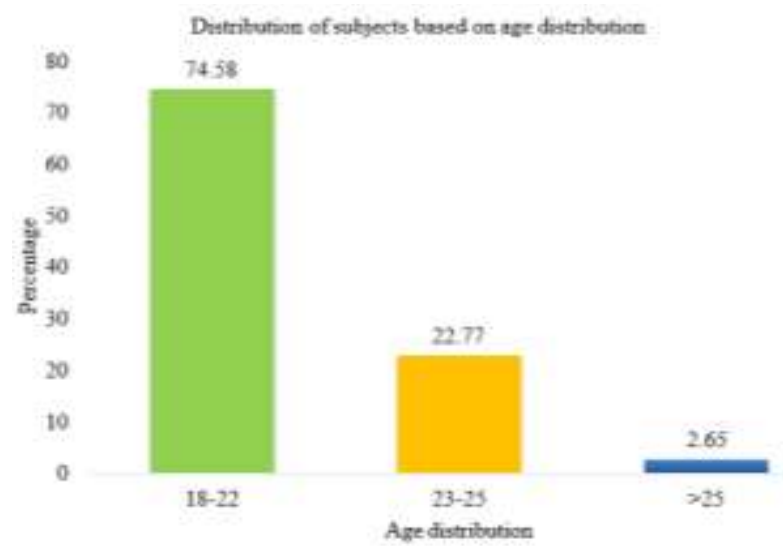

Figure 1: Distribution of subjects based on Age

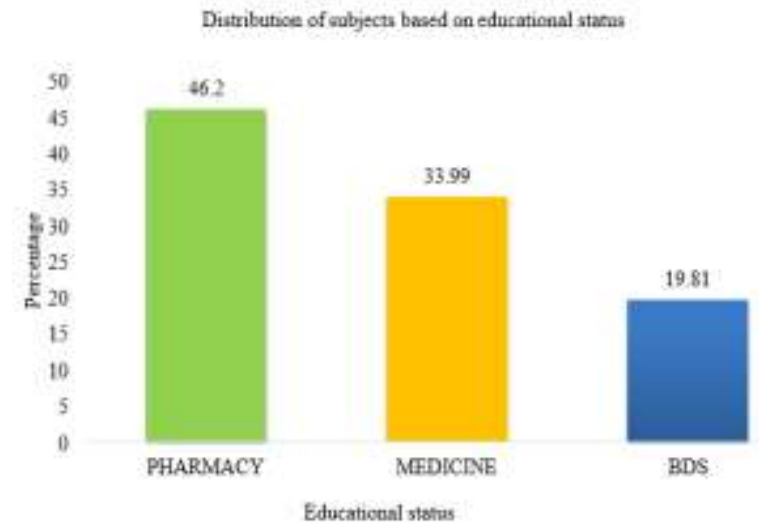

Figure 2: Distribution of subjects based on Educational Status

Distribution of Subjects Based on Residential Status

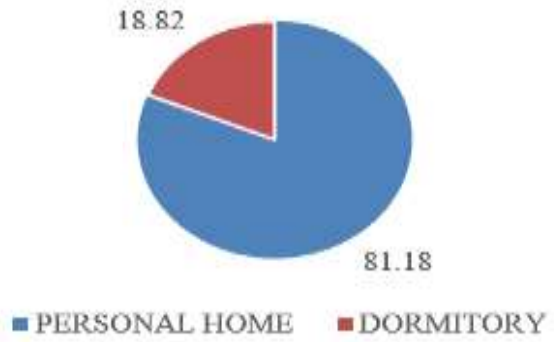

Figure 3: Distribution of subjects based on Residence Prevalence of Depression Based on DASS-21:

Figure 4 illustrated the prevalence rate of depression in our study population $(n=303)$. It was found that majority $(37.9 \%)$ of the subjects were moderately depressed followed by $27.9 \%$ who were reported with mild form of depression. 
EXTREMELY SEVERE

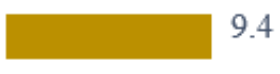

SEVERE

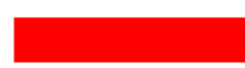

11

岂

\author{
MODERATE \\ MILD
}
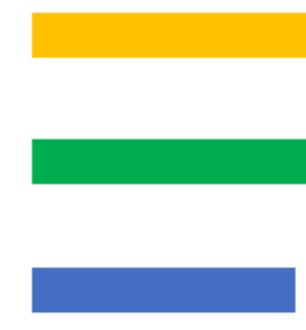

NORMAL

$$
0
$$

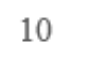

15

$25 \quad 30$

\section{Percentage}

Figure 4: Prevalence of Depression among study population

\section{Prevalence of Anxiety Based on DASS-21:}

The prevalence of anxiety in our study population $(n=303)$ is depicted in Figure 5. The bulk of the subjects (34.9\%) were moderately anxious, followed by 31.7 percent who had a mild form of anxiety, and $7.4 \%$ who had extremely severe anxiety. The study results are further detailed in Table-3.

\section{PREVALENCE OF ANXIETY}

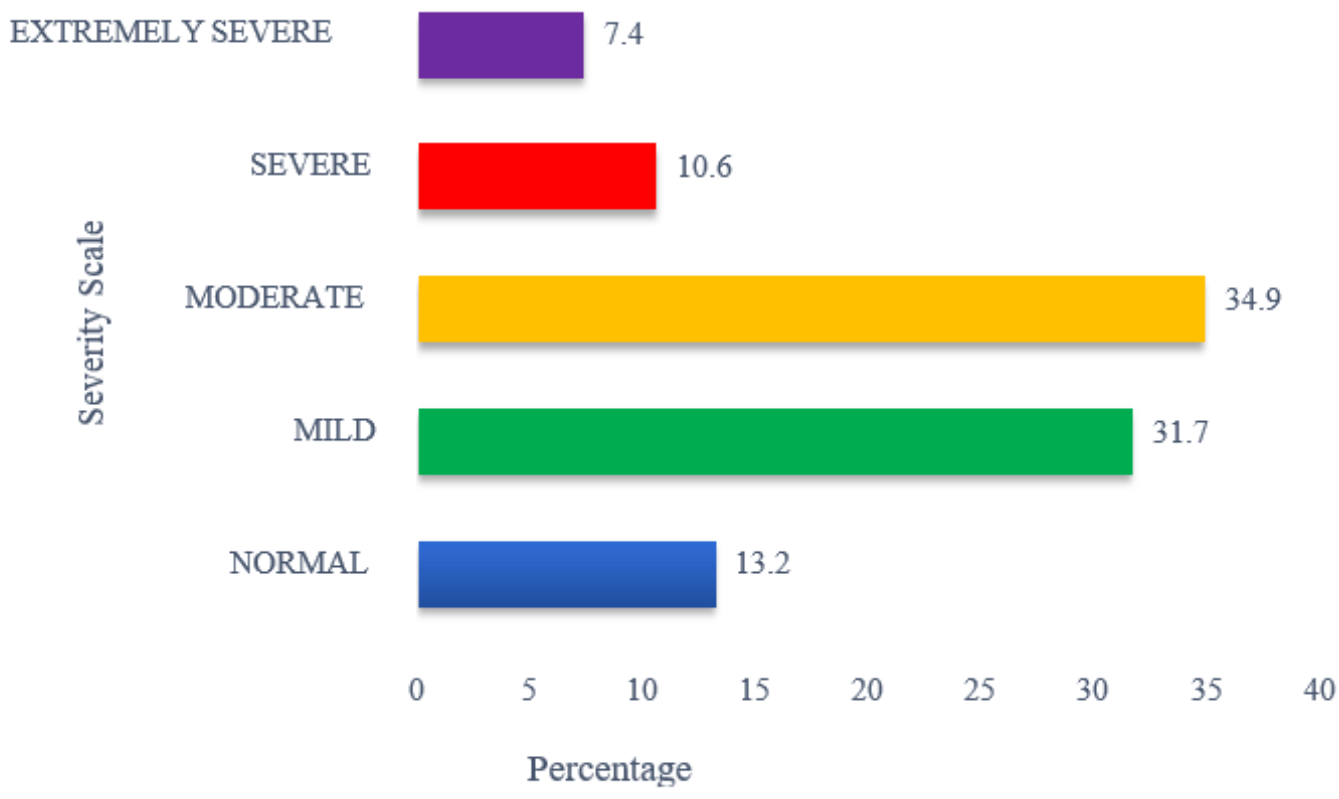

Figure 5: Prevalence of Anxiety among study population 


\section{Prevalence of Stress Based on DASS-21:}

The findings of our results illustrated that, majority of the individuals who are screened to assess the prevalence of the stress among the study subjects reported to have moderate level of stress ( $33 \%$ ), followed by $30.4 \%$ of the subjects who reported in the survey that they are subjected to severe stress during the pandemic and about $8 \%$ of the subjects are severely stressed. The study results are detailed in Table - 3 and Figure 8.

\section{PREVALENCE OF STRESS}

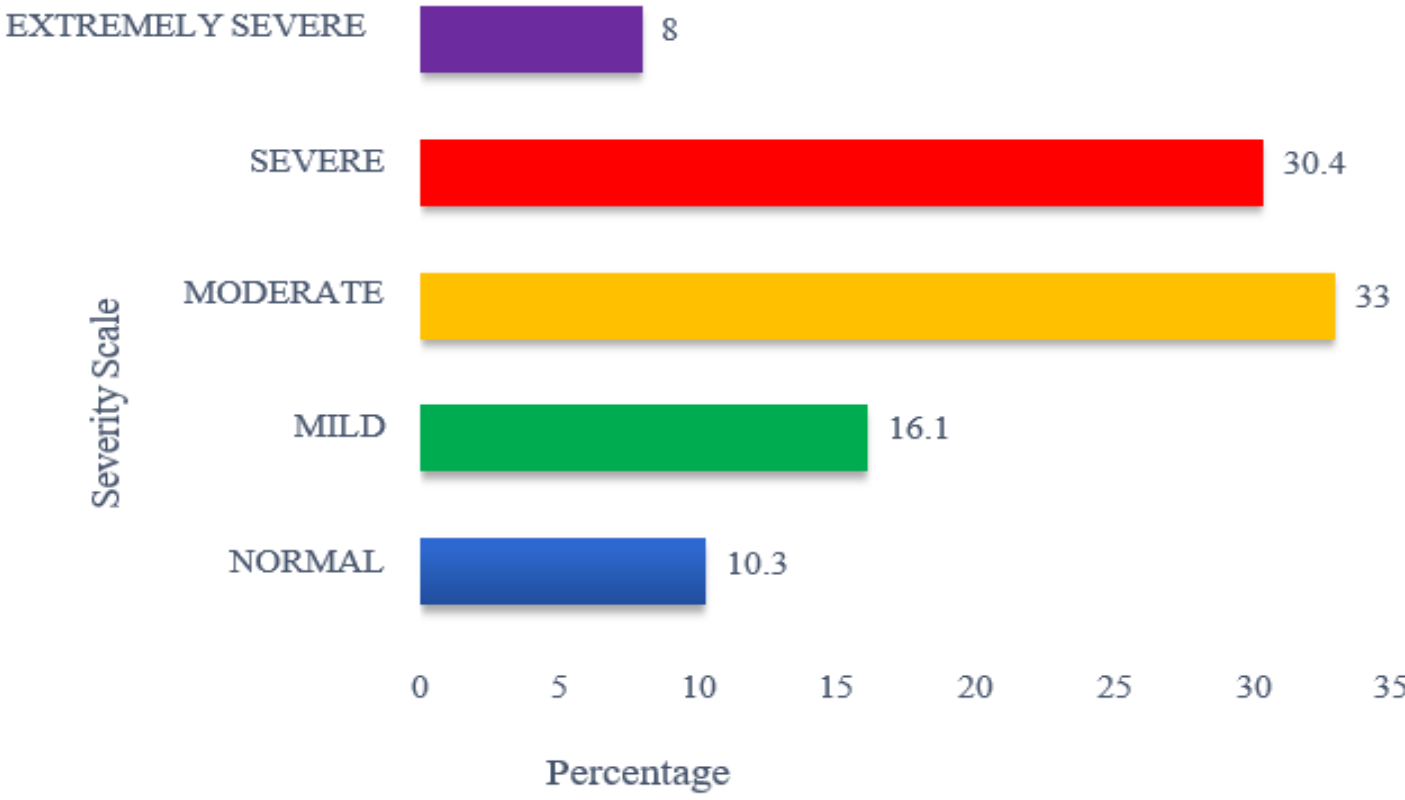

Figure 8: Prevalence of Stress among study population

Distribution level of depression, anxiety and stress (based on DASS 21 questionnaires):

Table 3. depicts the distribution of the depression, anxiety and stress levels among the healthcare students, out of 303 subjects only few subjects suffered from severe $111 \%)$ and extremely severe $(9.4 \%)$ levels of depression, at the same time $7.4 \%$ of the participants suffered from the extremely severe anxiety and $8 \%$ of the participants with extremely severe stress.

Table 3: Distribution level of Depression, Anxiety and Stress

\begin{tabular}{|l|l|l|l|}
\hline Levels & Depression (\%) & Anxiety (\%) & Stress (\%) \\
\hline Normal & $37(12)$ & $41(13.2)$ & $32(10.3)$ \\
\hline Mild & $86(27.9)$ & $98(31.7)$ & $50(16.1)$ \\
\hline Moderate & $117(37.9)$ & $108(34.9)$ & $102(33)$ \\
\hline Severe & $34(11)$ & $33(10.6)$ & $94(30.4)$ \\
\hline Extremely Severe & $29(9.4)$ & $23(7.4)$ & $25(8)$ \\
\hline
\end{tabular}

\section{Association between DASS-21 and Education Qualification:}

Chi-square test was performed to find the association between the educational qualification and DASS-21. A significant association was found in the depression $(<0.0001)$ and anxiety $(<0.00001)$ domains of the DASS-21 and students from pharmacy, medicine and dental. The results of the analysis displayed that the pharmacy and medicine students are more subjected to depression and anxiety. There was no significant association between stress level and educational qualifications of the subjects. The results of the test are illustrated in Table -4 . 
Table 4: Association of DASS-21 and Educational Qualification

\begin{tabular}{|c|c|c|c|c|c|c|c|}
\hline \multicolumn{8}{|c|}{ Depression } \\
\hline & & Normal $(0-4)$ & Mild (5-6) & $\begin{array}{l}\text { Moderate (7 - } \\
10)\end{array}$ & $\begin{array}{l}\text { Severe (11 - } \\
13)\end{array}$ & $\begin{array}{l}\text { Extremely } \\
\text { severe }(\geq 14)\end{array}$ & \\
\hline \multirow{3}{*}{ Education } & Pharmacy & 14 & 43 & 53 & 14 & 16 & \multirow{3}{*}{$p<0.0001^{*}$} \\
\hline & Medicine & 5 & 13 & 27 & 24 & 34 & \\
\hline & Dental & 9 & 9 & 29 & 7 & 6 & \\
\hline \multicolumn{8}{|c|}{ Anxiety } \\
\hline & & Normal(0 - 4) & Mild (4 - 5) & Moderate(6-7) & Severe(8-9) & $\begin{array}{l}\text { Extremely } \\
\text { severe }(\geq 10)\end{array}$ & \\
\hline \multirow[t]{3}{*}{ Education } & Pharmacy & 8 & 18 & 21 & 35 & 58 & \multirow[t]{3}{*}{$p<0.00001^{*}$} \\
\hline & Medicine & 14 & 28 & 41 & 10 & 10 & \\
\hline & Dental & 8 & 27 & 19 & 3 & 3 & \\
\hline \multicolumn{8}{|c|}{ Stress } \\
\hline & & $\operatorname{Normal}(0$ - 7) & Mild (8-9 & $\begin{array}{l}\text { Moderate(10 - } \\
12)\end{array}$ & Severe (13 - 16) & $\begin{array}{l}\text { Extremely } \\
\text { severe( } \geq 17)\end{array}$ & \\
\hline \multirow{3}{*}{ Education } & Pharmacy & 14 & 16 & 47 & 47 & 16 & \multirow{3}{*}{$p=0.182379$} \\
\hline & Medicine & 9 & 20 & 35 & 34 & 5 & \\
\hline & Dental & 9 & 14 & 20 & 13 & 4 & \\
\hline
\end{tabular}

* statistically significant value of $p<0.05$

\section{Association between DASS-21 and Gender:}

Table 5 illustrates the results of chi-square test performed to find the association between the gender and DASS-21. It was noted that there is a significant association between gender and depression ( $p=0.02852)$ and Anxiety $(p=0.02852)$ domain of the DASS-21. Indicating females are more associated with the depression and anxiety than males.

Table 5: Association between DASS-21 and Gender

\begin{tabular}{|c|c|c|c|c|c|c|c|}
\hline \multicolumn{8}{|c|}{ Depression } \\
\hline & & $\operatorname{Normal}(0-4)$ & Mild (5-6) & Moderate (7 - 10 & Severe (11 - 13) & $\begin{array}{l}\text { Extremely severe } \geq \\
14)\end{array}$ & \\
\hline \multirow[b]{2}{*}{ Gender } & Male & 16 & 44 & 52 & 15 & 12 & \multirow[t]{2}{*}{$p=0.02852^{*}$} \\
\hline & Female & 17 & 30 & 64 & 25 & 28 & \\
\hline \multicolumn{8}{|c|}{ Anxiety } \\
\hline & & $\operatorname{Normal}(0-4)$ & Mild (4-5) & Moderate(6-7) & Severe(8-9) & $\begin{array}{l}\text { Extremely severe( } \geq \\
10)\end{array}$ & \\
\hline \multirow[t]{2}{*}{ Gender } & Male & 18 & 48 & 50 & 15 & 8 & \multirow[t]{2}{*}{$p=0.000019^{*}$} \\
\hline & Female & 18 & 35 & 41 & 31 & 39 & \\
\hline \multicolumn{8}{|c|}{ Stress } \\
\hline & & $\operatorname{Normal}(0-7)$ & Mild (8-9 & $\begin{array}{l}\text { Moderate(10 - } \\
12)\end{array}$ & Severe $(13-16)$ & $\begin{array}{l}\text { Extremely severe }(\geq \\
17)\end{array}$ & \\
\hline \multirow[b]{2}{*}{ Gender } & Male & 14 & 22 & 52 & 36 & 15 & \multirow[b]{2}{*}{$p=0.25029$} \\
\hline & Female & 18 & 28 & 50 & 58 & 10 & \\
\hline
\end{tabular}

\footnotetext{
* statistically significant value of $p<0.05$
}

\section{Association between DASS-21 and Residence:}

The association between DASS-21 and Residence was calculated by performing Chi-square test and the results of the analysis depicted that there is a significant association in depression and stress among the subjects who reside at their personal home than compare to those who stay at the dormitory. The study results are detailed in Table 6 . 
Table-6: Association between DASS-21 and Residence

\begin{tabular}{|c|c|c|c|c|c|c|c|}
\hline \multicolumn{8}{|c|}{ Depression } \\
\hline & & $\operatorname{Normal}(0-4)$ & Mild (5-6) & $\begin{array}{l}\text { Moderate (7 - } \\
10)\end{array}$ & $\begin{array}{l}\text { Severe (11 - } \\
13)\end{array}$ & $\begin{array}{l}\text { Extremely } \\
\text { severe }(\geq 14)\end{array}$ & \\
\hline & PersonalHome & 23 & 29 & 110 & 57 & 27 & \\
\hline Residence & Dormitory & 6 & 20 & 20 & 6 & 5 & $p=0.0004^{*}$ \\
\hline \multicolumn{8}{|c|}{ Anxiety } \\
\hline & & $\begin{array}{l}\text { Normal } \\
(0-4)\end{array}$ & Mild (4-5) & Moderate(6-7) & Severe(8-9) & $\begin{array}{l}\text { Extremely } \\
\text { severe }(\geq 10)\end{array}$ & \\
\hline \multirow[b]{2}{*}{ Residence } & Personal Home & 42 & 49 & 54 & 23 & 78 & \multirow[b]{2}{*}{$p=0.08$} \\
\hline & Dormitory & 9 & 20 & 19 & 6 & 3 & \\
\hline \multicolumn{8}{|c|}{ Stress } \\
\hline & & $\operatorname{Normal}(0-7)$ & Mild (8-9 & $\begin{array}{l}\text { Moderate(10 - } \\
12)\end{array}$ & Severe $(13-16)$ & $\begin{array}{l}\text { Extremely } \\
\text { severe }(\geq 17)\end{array}$ & \\
\hline & PersonalHome & 27 & 40 & 83 & 75 & 21 & \multirow[b]{2}{*}{$p=0.0006^{*}$} \\
\hline Residence & Dormitory & 13 & 9 & 16 & 18 & 1 & \\
\hline
\end{tabular}

\section{DISCUSSION:}

During the corona virus epidemic, students were at risk for a variety of mental health issues. During the COVID-19 outbreak, our data revealed stress, anxiety, and depression symptoms among Healthcare students. The most severe kind of depression among the students was identified, followed by anxiety and stress. College student's anxiety over COVID19 may be related to the virus's impact on their studies and their inability to cope with the virus's repercussions. Their tension, on the other hand, could have been induced by them gradually losing focus in their online classes over the confinement period. Stress and fury have been linked to a variety of undesirable psychological behaviors and mental illnesses.

In current study carried out from April 26th to May 20th, 2021, healthcare students were asked to complete a questionnaire that included demographic information and a patient health questionnaire. We measured mental health status of subjects using DASS-21, which was retrieved from the DASS website. DASS-21 was proven to be valid screening instrument for assessing depression, anxiety and stress among general population. A total of 303 participated in cross-sectional survey, majority were between the age group of 18-22 followed by age group 23- 25 years.

Study conducted by Hans Mautong et al colleagues to investigate the levels of depression, anxiety, and stress in the Ecuadorian general population during the COVID-19 outbreak, the Depression, Anxiety, and Stress Scale-21 Items (DASS-21) questionnaire was used to examine mental health. A total of 626 participants were included. Majority of them were females (60.5\%), and approximately $17.7 \%$ of the respondents had moderate to very severe levels of depression, $30.7 \%$ had similar levels of anxiety, and $14.2 \%$ experienced stress. This finding is lower than the study we undertook to assess the prevalence of depression which found to be $37.9 \%$ moderate and $27.9 \%$ mild among 303 participants, while the prevalence of anxiety was 34.9 percent moderate to 31.7 mild and the stress rate to be 33 percent moderate to 30.4 percent severe. Similarly in our study majority were females $(54.13 \%)$. The depression rate was $37.9 \%$ moderate to $27.9 \%$ mild, anxiety rate was $34.9 \%$ moderate to $31.7 \%$ mild and stress rate was found to be $33 \%$ moderate to $30.4 \%$ severe. The current research was conducted during the COVID-19 epidemic. This could be the reason for the rise in the number of people in our study who are depressed. ${ }^{2}$

When the DASS scores of males and females in the study were particularly in comparison, it was observed that males had slightly lower scores than females in all 21 DASS questionnaire survey that the participants delivered, but there were no statistically significant differences in the DASS Scores between the study subjects based on gender. We evaluated our outcomes to those of another study, in which Na Jiang et .al investigated depression, anxiety, and stress among students during the COVID-19 epidemic. According to the data, up to $38 \%$ of students said they were unhappy, concerned, or tense in some form, with 20.5 percent saying they had severe or extremely severe anxiety. The most common ailment among students was anxiety, which was followed by depression. Their study investigates the assistance and services available to assist students with mental health concerns and provides an overview of student mental health challenges. ${ }^{4}$

Contrary to this, the study conducted by Addisu Tadesse Sahile $\boldsymbol{e t}$.al on 153 college students pandemic of COVID-19 among college students in addis Ababa, Ethiopia, 2020. The overall prevalence of depression was $51 \%$ of which $49 \%$, $18.1 \%, 20.9 \%, 7.2 \%$, and $4.6 \%$ of participants had normal, mild, moderate, severe and extremely severe depression consecutively.20 The overall prevalence of anxiety was 51.6 where $11 \%, 20.9 \%, 6.5 \%$, and $13.1 \%$ of the participants had mild, moderate, severe, and extremely severe anxiety symptoms respectively. The magnitude of stress was $11.1 \%$ of which only $7.8 \%$ and $2.6 \%$ had mild and moderate stress symptoms. Their study revealed a higher prevalence of depression and anxiety, as well as a higher degree of stress. Notably our research found that $37.9 \%$ of students suffered from serious depression and $27.9 \%$ from mild depression, anxiety was found to be prevalent in 34.9 percent of the population, while stress was found to be prevalent in 33 percent of the population, ranging from moderate to severe. ${ }^{13}$ 
On comparing the impacts of educational status among subjects $46.2 \%$ of scholars were from pharmacy profession ,33.99\% from MBBS and 19.81\% were from BDS Profession among which majority of the females were affected by moderate sort of depression. This finding is analogous to the survey conducted by Susheela Rana et .al during COVID-19 pandemic and better many depression, anxiety \& stress were recorded among the primary year MBBS students; females having more scores than male students. This study highlights the importance of and wish for routine screening of depression, anxiety and stress among medical students especially females. similarly the findings of our study displayed that there is a significant association with depression and anxiety with the gender, indicating females are more associated with depression and anxiety than males. It was also noticed that there was a significant association with depression and stress among those who are residing at home and dormitory. The study results indicated that, among the subjects those who were staying at personal home have suffered more from depression and stress than those who are staying at dormitory. ${ }^{14}$

Based on the results of this study, we suggest that colleges and universities should provide students with tailored psychological guidance, considering that college students in different years may have differentiated psychological wellbeing status. Universities may offer proper psychological counseling for freshman students in order to relieve their anxiety and pay special attention to improving the psychological well-being of sophomore students. Furthermore, it is worth noting that the overall optimistic situation of the psychological state of colleges students may be due to their weak perception about changes in their external social environment. In the future, we could study college students' mental changes after entering the labor market for a certain period. The comparison of their psychological situation at work and during college could be explored to offer more implications on the development of psychological well-being counseling programs in college.

\section{CONCLUSION}

According to our findings, the majority of healthcare students had moderate depression, followed by worry and stress. Females are more likely than males to suffer from depression and anxiety, according to the research, although stress levels are about the same in both genders. This study found that during the covid-19 epidemic, pupils are more likely to experience psychological discomfort. It is necessary to make efforts to develop positive mental health and wellbeing, as well as to monitor and promote it to alleviate the pandemic's negative impacts, particularly in highly vulnerable women. Further research is needed in the future to uncover socio-demographic characteristics and other aspects related to academic curriculum in medical institutions so that remedial measures can be offered as soon as possible; otherwise, not only the medical community but society as a whole would suffer. For this cause we recommend some of the measures like staying healthy, forming a study group, maintaining a close group of friend, engaging in social activities, participating in extracurricular events etc.

\section{ACKNOWLEDGEMENT:}

Research team would like to thank all the students who participated in the present study and provided their valuable responses.

Conflict of Interest: None

\section{Source of Funding: None}

\section{REFERENCES:}

1. Odriozola-González P, Planchuelo-Gómez Á, Irurtia M, de LuisGarcía R. Psychological effects of the COVID-19 outbreak and lockdown among students and workers of a Spanish university. Psychiatry Research. 2020; 290:113108.

https://doi.org/10.1016/j.psychres.2020.113108

2. Mautong H, Gallardo-Rumbea J, Alvarado-Villa G, FernándezCadena J, Andrade- Molina D, Orellana-Román C et al. Assessment of depression, anxiety and stress levels in the Ecuadorian general population during social isolation due to the COVID- 19 outbreak: a cross-sectional study. BMC Psychiatry. 2021; 21(1). https://doi.org/10.1186/s12888-021-03214-1

3. Alkhamees A, Alrashed S, Alzunaydi A, Almohimeed A, Aljohani M. The psychological impact of COVID-19 pandemic on the general population of Saudi Arabia. Comprehensive Psychiatry. 2020; 102:152192.

https://doi.org/10.1016/j.comppsych.2020.152192

4. Jiang N, Yan-Li S, Pamanee K, Sriyanto J. Depression, Anxiety, and Stress During the COVID-19 Pandemic: Comparison Among Higher Education Students in Four Countries in the Asia-Pacific Region. Journal of Population and Social Studies. 2021; 29:370383. https://doi.org/10.25133/JPSSv292021.023

5. Bhattacharya, Amit (24 May 2021). "India's Covid toll tops 3 lakh, 50,000 deaths in 12 days". The Times of India. Retrieved 24 May 2021.

6. Coker A, Coker O, Sanni D. Psychometric properties of the 21-item Depression Anxiety Stress Scale (DASS-21). African Research Review. 2018; 12(2):135. https://doi.org/10.4314/afrrev.v12i2.13

7. Andrews M, Areekal B, Rajesh K, Krishnan J, Suryakala R, Krishnan B et al. First confirmed case of COVID-19 infection in India: A case report. Indian Journal of Medical Research. 2020; 151(5):490. https://doi.org/10.4103/ijmr.IJMR_2131_20

8. Fox D. What you need to know about the novel coronavirus. Nature. 2020; https://doi.org/10.1038/d41586-020-00209-y

9. Sahoo S, Rani S, Parveen S, Pal Singh A, Mehra A, Chakrabarti S et al. Self-harmand COVID- 19 Pandemic: An emerging concern - A report of 2 cases from India. Asian Journal of Psychiatry. 2020; 51:102104. https://doi.org/10.1016/j.ajp.2020.102104

10. Huang Y, Zhao N. Generalized anxiety disorder, depressive symptoms and sleep quality during COVID-19 outbreak in China: a web-based cross-sectional survey. Psychiatry Research. 2020; 288:112954.

https://doi.org/10.1016/j.psychres.2020.112954

11. Hall R, Hall R, Chapman M. The 1995 Kikwit Ebola outbreak: lessons hospitals andphysicians can apply to future viral epidemics. General Hospital Psychiatry. 2008; 30(5):446-452. https://doi.org/10.1016/j.genhosppsych.2008.05.003

12. Verma S, Mishra A. Depression, anxiety, and stress and sociodemographic correlates among general Indian public during COVID-19. International Journal of Social Psychiatry. 2020; 66(8):756-762. https://doi.org/10.1177/0020764020934508

13. Sahile A, Ababu M, Alemayehu S, Abebe H, Endazenew G, Wubshet $\mathrm{M}$ et al. Prevalence and severity of homestay followed depression, anxiety, and stress during pandemics of covid-19 among college students in Addis Ababa, Ethiopia, 2020. A cross sectional survey. Journal of Psychology and Clinical Psychiatry. 2021; 12(1):5-8. https://doi.org/10.15406/jpcpy.2021.12.00695

14. Rana S, Taywade O, Sharma V, Hiwarkar M. Study of depression, anxiety and stress among first year Medical students in Government Medical College, Himachal Pradesh during COVID19 pandemic. Asian Journal of Medical Sciences. 2021; 12(6):7074 https://doi.org/10.3126/ajms.v12i6.36687 